\title{
The Principal Contradiction of Higher Education Development in the New Era*
}

\author{
Haisha $\mathrm{Su}$ \\ Kunming Metallurgy College \\ Kunming, China
}

\begin{abstract}
China has entered a new era. The transformation of social principal contradiction is also reflected in the field of higher education. Higher education as an important support for economic development, social transformation and implementation of national strategy, we need to recognize and face these contradictions and gradually solve them.
\end{abstract}

Keywords-new era; higher education development; the principal contradiction

\section{INTRODUCTION}

In October 2017, the Nineteenth National Congress of the Communist Party of China was successfully convened. The meeting pointed out that China has entered a new era of socialism with Chinese characteristics. The contradiction between the growing material and cultural needs of the people and the backward social production, which has been put forward by the Eighth National Congress of the Communist Party of China (CPC), has been transformed into the contradiction between the growing needs of the people for a better life and the unbalanced development. This is an accurate judgment of the historical orientation of China's social development, reflecting the phased requirements of China's development, as well as the key requirements of the development of China's undertakings. In the 40 years since the reform and opening up, the level of China's social productive forces has been remarkably improved, the social productive capacity has been ranked in the forefront of the world in many respects, the living standard of the people has been remarkably improved, and the needs of the masses have exceeded the scope and level of material culture in the realm and gravity of the needs of the masses. There are many factors that influence the satisfaction of the people's needs for a better life, but the main problem is the imbalance of development. Therefore, based on continuing to promote development, we should strive to solve the problem of uneven development and better meet the growing needs of the people in economic, political, cultural, social, and ecological fields.

Building a powerful country of education is the basic project of the great rejuvenation of the Chinese nation. Since the resumption of the college entrance examination in 1978, China's higher education has made remarkable progress and

*Yunnan Provincial "Double hundreds and Double Entry" Research Fund Project in 2016. achieved remarkable results. With the arrival of the new era of socialism with Chinese characteristics, the transformation of social principal contradictions is also embodied in the field of higher education. It is also necessary for us to gradually resolve these contradictions based on promoting development and meet the needs of the masses for higher education.

\section{THE DEVELOPMENT OF HIGHER EDUCATION IS THE SOLID BASIS FOR THE GREAT REJUVENATION OF THE CHINESE NATION}

As the supporting force of socio-economic development and social transformation, the Ministry of Education has successively implemented the construction of "211 Project", "985 Project" and "world first-class universities and firstclass disciplines" in the field of general higher education, and the construction of demonstration colleges, "high-level schools and high-level specialties" and high-quality colleges and universities in the field of higher vocational education to effectively promote the development of various disciplines and disciplines, effectively support the implementation of the national development strategy, and ensure the development of economy, politics, culture, society and ecology.

As an important part of safeguarding and improving the people's livelihood, in 1999, after the popularization of higher education, the scale of higher education in China grew rapidly, and the gross enrollment rate reached $42.7 \%$ in 2016 . More school-age youths have entered higher education institutions for further study and have more development options and broader prospects for development.

Since the forty years of reform and opening up, higher education has played an irreplaceable role in the implementation of the national development strategy. Infrastructure construction related to people's livelihood, such as high-speed rail, has benefited from the support of higher education. Important scientific and technological achievements such as Tiangong, Jiaolong and Tianyan benefit from the foundation of higher education. The construction of innovative country benefits from the strong support of higher education. The development of higher education is a solid foundation of the great rejuvenation of the Chinese nation. 


\section{EMBODIMENT OF SOCIAL PRINCIPAL CONTRADICTIONS IN THE FIELD OF HIGHER EDUCATION IN THE NEW ERA}

Along with the social development entering the new era, the social principal contradiction has also had the outstanding performance in the higher education field, which is specifically reflected as the contradiction between the requirement of social development and the people for the high-quality and high-level higher education and insufficient and unbalanced development of the higher education.

\section{A. Contradictions between the Needs of Social Development and the Insufficient Development of Higher Education}

The 18th National Congress of the Communist Party of China (CPC) has put forward two goals for one hundred years: to build a well-off society of a higher level benefiting more than a billion people in the 100 years since the founding of the Communist Party of China (CPC), and to basically realize modernization and to build a modern socialist country in the 100 years since the founding of the People's Republic of China. The Nineteenth National Congress of the Communist Party of China (CPC) advances the development plan and put forward the goal of "two phases" to basically realize socialist modernization from 2020 to 2035 . From 2035 to the middle of this century, we will build a prosperous, strong, democratic, civilized, harmonious, beautiful, socialist, modernized and powerful country. Both building a well-off society in an all-round way and building a socialist modernized and powerful country put forward higher requirements on personnel training, scientific research, serving the society and cultural inheritance of higher education and the current development of higher education cannot fully meet the requirements of social development objectives.

\section{B. The Contradiction between the People's Expectations of Social Equity and the Unbalanced Regional Development of Higher Education}

Social fairness calls for education fairness. To a great extent, the fairness of education is embodied in the fairness of urban and rural basic education and the regional fairness of higher education. The imbalance of the regional development of higher education has a significant impact on the poverty alleviation in the central and western povertystricken areas of China.

The imbalance of regional development of higher education is mainly embodied in the imbalance of development between the eastern and the central and western regions, and there is a tendency of widening the gap. There are 76 colleges and universities directly under the Ministry of Education, which are located in 18 provinces and municipalities such as Beijing and Shanghai, while 13 provinces and autonomous regions where there isn't university directly under the Ministry of Education are located in the central and western regions. The research results of the research group of the Ministry of Education on the distribution and coordinated development of China's higher education resources show that the distribution of China's existing higher education resources is extremely uneven, and higher education resources in the central and western regions, especially the western undeveloped regions, are rather scarce. Due to the influence of economic development and resource allocation, the gap brought by the flow of high-quality teachers in the east and the input of funds has led to the unfairness of the development opportunities of higher education. The development of higher education in a region plays the role of firming root, sowing seed and culturing seed in the introduction and cultivation of regional talents and plays a leading role in the development of regional economy and society. The unfair development opportunity of higher education is an important reason for the uneven regional economic and social development.

The comparison between Xi'an Jiaotong University and Shanghai Jiaotong University can give us a clear understanding. The annual budget for 2016 is 11.803 billion yuan for Shanghai Jiaotong University and 5.637 billion yuan for Xi'an Jiaotong University. As for teachers, there are 47 academicians of the Chinese Academy of Sciences and Chinese Academy of Engineering in 70 scholars of the "Thousand Talents Program" and 39 academics of the "Thousand Youth Talents Program" Shanghai Jiaotong University by 2015 . There are 29 academicians and totally 51 academics of "Thousand Talents Program" and "Thousand Youth Talents Program" in Xi'an Jiaotong University. It is worth mentioning that although Xi'an Jiaotong University is located in the central and western regions, it is a university directly under the Ministry of Education. Both the fund budget and faculty are the best in the central and western regions, and it is difficult for other colleges and universities to compare with it. It can be seen that ordinary colleges and universities have constraints in the budget.

\section{The Contradiction between the Requirements of} Implementing the Strategy of Manufacturing Power and the Unbalanced Development of General Higher Education and Higher Vocational Education

General higher education and higher vocational education are basically equal from the number of schools. In addition to the large gap in the input and resource allocation, there is also a large gap between the two in the characteristics of talent training and the connotative development of schools. "Made in China 2025", issued by the State Council in 2015, is the program of action for the implementation of the strategy of manufacturing power. As the support and guarantee of the development of China's manufacturing industry, higher vocational education must follow the road of connotation development, cultivate the talents who can promote the industrial reform and accelerate the transformation of the economic development mode, and support the development of the national strategy. 
D. The Contradiction between the Social Demand for Diversified Education and the Uneven Development of Public and Private Colleges and Universities

Private colleges and universities are a beneficial supplement to higher education in China. In 2016, there were $7,486,100$ undergraduate students enrolled in general higher education, of which 724 private colleges (including 266 independent colleges) had a total enrollment of 1,818,300, accounting for 24.3 percent. However, there is not yet a privately-run college with high level that is generally recognized by the society. People choose private colleges and universities often accompanied by psychological gap.

At present, in addition to tuition income, the main source of funding for public colleges and universities is government funding, while the main source of funding for private colleges and universities is the investment from sponsors. The gap between the two sources of funding is obvious, and the development gap brought about is also obvious. At present, the main energy of private colleges and universities is still on the enrollment. From the perspective of teaching quality and management norms, there is still a considerable distance from the requirements of the masses, which also makes the social evaluation of private colleges and universities lower. Private colleges and universities are still in the initial stage of development, and the social reputation and social evaluation, social donation and alumni donation is almost zero. The lack of funds, the slow development of school connotation, and the lack of school characteristics will make it easy for schools to fall into a vicious circle. Contrary to the general situation of private universities and public universities in the United States, most private universities in the United States have a relatively large proportion of private donations and schools are more comfortable in the introduction of teachers and funds for research and development, so it has more security and advantage in improving the quality of teaching and personnel training level.

\section{SOLVING THE PRINCIPAL CONTRADICTIONS OF \\ HIGHER EDUCATION IN THE PROCESS OF DEVELOPMENT}

On one hand, it takes ten years to grow a tree and a hundred years to bring up a generation of good men. We should calm down and do a good job in teaching and educating people on a down-to-earth basis. We should not be overly influenced by the ranking of all kinds of universities and should be patient and tolerant of the development and growth of higher education in China.

Second, targeted guidance should be made to the higher education institutions of all types and levels to promote the characteristic development of colleges and universities and accelerate the connotative development of higher education. The starting point and the foothold of the characteristic development of colleges and universities is to promote the connotation development of higher education. The connotation development of higher education is a comprehensive requirement, so we should have a fundamental understanding and change of concept of running a school, the mode of personnel training, and the evaluation system.

Third, the investment in higher education institutions should be considered in accordance with the requirements of the new era. At the beginning of reform and opening up, the college entrance examination system has been restarted and higher education in China also restarted. At that time, the state's financial resources were weak, and a number of colleges and universities were trained and supported with emphasis, which indeed played a leading and exemplary role in the development of higher education, and played a significant role in promoting the country's economy, politics, culture, and society. As the country develops and grows, priority should be given to support the weakest and most urgent regions and colleges and universities in terms of funding. For most of the ordinary undergraduate colleges and universities, which are not "985", "211" and "double-firstclass" construction, especially the higher vocational colleges, we should pay enough attention and relatively reasonable investment to reduce the gap between the development of the regions and the gap between the schools reasonably to make higher vocational education in China develop in the connotation construction. This promotes the balanced development of economy and society in the east, the middle and the west, and has a direct effect on the promotion of social equity.

Fourth, at the policy level, we should support the characteristic development and high-level development of private colleges and universities. The healthy development, characteristic development and high-level development of private colleges and universities cannot be separated from the support of national policies. "High-level private colleges and universities special support projects" to a certain extent improve the level of private colleges and universities; The national policy of student aid and reward, the construction of educational practice base and the supporting policy of the national teacher training program have covered the private colleges and universities. On this basis, we should continue to increase the support to the private colleges and universities, and further implement the Law on the non-state educating promoting law. In the policy guidance, we support to encourage the majority of enterprises to participate in the construction of private colleges and universities, so that private colleges and universities have the strength to focus on the quality of running schools and the connotative development.

\section{CONCLUSION}

To realize the great rejuvenation of the Chinese nation, education takes precedence. In the field of higher education, this is a mission shared by more than 2,000 colleges and universities across China. The unbalanced development in higher education field is a problem in the process of development, which should be solved gradually by development. 


\section{REFERENCES}

[1] 2016 statistical bulletin on national educational development of Ministry of Education http://www.moe.edu.cn/jb_sjzl/sjzl_fztjgb/201707/t710_309042. htm 教育部 2016 年全国教育事业发展统计公报 http://www.moe.edu.cn/jyb_sjzl/sjzl_fztjgb/201707/t20170710_3090 42.htm

[2] Zhou Jiansong. Construction of High-level Higher Vocational Colleges Based on Connotation Development [J] Chinese Vocational and Technical Education, 2018. 1. 周建松 基于内涵发展的高水平 高职院校建设【J】中国职业技术教育 2018 年 1 月

[3] Chen Pingyuan. Mianland/Hong Kong Mutual Participation: Independence and Confidence of Chinese Universities [J] Exploration and Free Views, 2014, 9. 陈平原 内地/香港互参: 中国大学的独立与 自信【J】探索与争鸣 2014 年 9 月

[4] Qian Wei. The polarization of Dvelopment of Chinese University is Serious Central and Western Colleges and Universities are Still "ransacked" [J] China Newsweek, 2017, 6. 钱炜 中国大学发展两极 化严重中西部高校还在 “被掠夺”【J】中国新闻周刊 2017 年 6 月 